\title{
The response of rats to solanidine glycoalkaloids and trypsin inhibitor present in potato protein concentrates, and to glycoalkaloids provided by potato sprouts
}

\author{
A. Tuśnio', B. Pastuszewska, M. Taciak, M. Barszcz and J. Skomiał \\ The Kielanowski Institute of Animal Physiology and Nutrition, Polish Academy of Sciences \\ 05-110 Jabłonna, Poland
}

KEY WORDS: potato protein, solanidine glycoalkaloids, trypsin inhibitor, rats

Received 4 April 2012

Revised 4 June 2013

Accepted 17 June 2013

${ }^{1}$ Corresponding author: e-mail: a.tusnio@ifzz.pan.pl

\begin{abstract}
The effects of potato protein concentrates (PPC) differing in dietary solanidine glycoalkaloids (SGA) and trypsin inhibitor activity (TI), and of potato sprouts with differing SGA levels, were studied in rats. In Experiment 1, semi-purified isoprotein diets containing casein or one of six PPC contributing from 116 to $439 \mathrm{mg} \mathrm{SGA} \cdot \mathrm{kg}^{-1}$ and from 0.13 to $0.45 \mathrm{mg} \cdot \mathrm{g}^{-1}$ of TI activity, were used. Weight gain was significantly greater on the diet containing PPC with low SGA and low TI than on PPC with high SGA and moderate TI contents, and also higher than on casein. Weight gain was also slightly depressed on diets with the highest $\mathrm{TI}$ activity. Substitution of PPC for casein resulted in lowering the $\mathrm{pH}$ of caecal digesta and increasing short-chain fatty acids concentration. Feeding diets with the greatest SGA content induced depression of protein and organic matter digestibility while diets with the greatest TI activity decreased protein digestibility but did not affect pancreas weight. In Experiment 2, a commercial rat diet, supplemented with increasing amounts of potato sprout meal providing SGA in the range from 0 to $300 \mathrm{mg} \cdot \mathrm{kg}^{-1}$, was used. Neither growth performance, organ weights, caecal parameters, nor enzyme activities were affected by the diet. It is postulated that the less evident response of rats to SGA in the natural ingredient than in the semi-purified diet was due to the attenuating effect of more intensive bacterial fermentation. Potato trypsin inhibitor should be considered as an antinutritional factor in PPC; interactive effects of SGA and TI are presumable.
\end{abstract}

\section{Introduction}

Potato protein concentrate (PPC) is one of a few vegetable protein sources having an excellent amino acid composition that can replace animal protein in piglet and chicken diets. There are, however, several factors which limit the efficient use of PPC such as solanidine glycoalkaloids (SGA) and trypsin inhibitor (TI), the resistance of potato protein to enzymatic digestion in rats (Morita et al., 2004; Taciak and Pastuszewska, 2007) and in pigs
(Tuśnio et al., 2011), and the stimulatory effect of potato protein on Clostridium perfringens infection and intestinal lesions in chicken (Palliyeguru et al., 2010; Fernando et al., 2011). Most of these effects concern the gut and can be interrelated, but SGA and TI seem to be primordial factors. Whereas the tolerance of different animal species to these compounds has not been established, knowledge about their antinutritional effects is important for the safe use of PPC, particularly because of its highly variable contents (Pastuszewska et al., 2009). 
In the experiments of Kerr et al. (1998), piglets fed on diets with different but low levels of PPC showed deterioration of feed intake and growth performance related to the solanidine glycoalkaloids content of PPC, but this relationship has not been quantified. In the experiments of Tuśnio et al. (2011) growing pigs performed well on a considerably higher dietary level of PPC and SGA than piglets used in the study by Kerr et al. (1998). Chickens appear to be less tolerant to dietary PPC than pigs and they seem to better tolerate increases in the dietary level of SGA than of the respective level of PPC (Tuśnio et al., 2013). This may indicate the presence of other factor(s) in PPC that lower its acceptability in birds. The inconsistency of the reported results may stem both from varying experimental design and from different susceptibility to SGA and PPC of the animal species under study.

The main methodological difficulty in studies on the tolerance of animals to SGA is separation of the effects of SGA from those of TI and of potato protein itself. Due to the very high price of synthetic forms of glycoalkaloids, it is most often impossible to use them as dietary additives and check their effects directly. Diets differing in SGA and TI, but uniform in PPC contents can be formulated only when PPC of known and diverse SGA concentrations and TI activity are available, as in the experiment of Tuśnio et al. (2013) on chickens. An alternative solution may be providing SGA using potato sprouts, which are a very rich source of these compounds. Both methodological approaches were applied in the present study performed on rats. Its objective was to determine the response of growing rats to increasing amounts of dietary glycoalkaloids contributed either by potato protein concentrate or by potato sprouts, and to approximate the effects of potato trypsin inhibitor present in PPC. Feed intake, growth rate, weight of the gastrointestinal tract and body organs, activity of selected liver enzymes, and intensity of bacterial fermentation in the caecum, were measured. Digestibility of organic matter and protein in diets containing different concentrations of SGA and TI activity were also determined.

\section{Material and methods}

\section{Diets}

Two experiments were performed. In Experiment 1 , six semisynthetic, isoprotein diets containing PPC (obtained from Polish starch factories) differing in SGA concentration and TI activity (diets No. 2 to 7), and a control diet containing casein (diet No. 1), were formulated. The composition of the diets is shown in Table 1. In Experiment 2, commercial Labofeed $\mathrm{H}$ diet for growing laboratory
Table 1. Composition of diets used in Experiment 1

\begin{tabular}{|c|c|c|c|c|c|c|c|}
\hline \multirow{2}{*}{ Indices } & \multicolumn{7}{|c|}{ Diet No } \\
\hline & 1 & 2 & 3 & 4 & 5 & 6 & 7 \\
\hline \multicolumn{8}{|l|}{ Ingredients, $\mathrm{g} \cdot \mathrm{kg}^{-1}$} \\
\hline casein & 124 & - & - & - & - & - & - \\
\hline $\begin{array}{l}\text { potato protein } \\
\text { concentrate }^{1}\end{array}$ & - & 134 & 134 & 135 & 136 & 133 & 132 \\
\hline maize starch & 626 & 616 & 616 & 615 & 614 & 617 & 618 \\
\hline constant ingredients ${ }^{2}$ & 2250 & 250 & 250 & 250 & 250 & 250 & 250 \\
\hline $\mathrm{SGA}^{3}, \mathrm{mg} \cdot \mathrm{kg}^{-1}$ & - & 116 & 125 & 164 & 215 & 331 & 439 \\
\hline $\mathrm{Tl}^{4}, \mathrm{mg} \cdot \mathrm{g}^{-1}$ & - & 0.42 & 20.13 & $3 \quad 0.45$ & $5 \quad 0.14$ & $4 \quad 0.29$ & $\begin{array}{ll}9 & 0.27\end{array}$ \\
\hline $\begin{array}{l}\text { Crude protein, } \\
\mathrm{g} \cdot \mathrm{kg}^{-1} \text { (analysed) }\end{array}$ & 99.4 & 4108.7 & 112.5 & 106.2 & 103.1 & 106.9 & 104.4 \\
\hline
\end{tabular}

${ }^{1}$ potato protein concentrate with different SGA and $\mathrm{Tl} ;{ }^{2}$ per $\mathrm{kg}$ of diet, g: saccharose 120 , cellulose 40 , soya oil 40 , minerals 35 , vitamin 10 , choline chloride 2 , chromium oxide $3 ;{ }^{3}$ solanidine glycoalkaloids; ${ }^{4}$ trypsin inhibitor activity

Table 2. Composition of diets used in Experiment 2

\begin{tabular}{lcccccc}
\hline Indices & Diet & \multicolumn{6}{c}{5} \\
\cline { 2 - 7 } & 1 & 2 & 3 & 4 & 5 & 6 \\
\hline Ingredients, $\mathrm{g} \cdot \mathrm{kg}^{-1}$ & & & & & & \\
Labofeed $\mathrm{H}$ & 960.0 & 958.6 & 957.1 & 955.7 & 954.3 & 952.8 \\
Rapeseed oil & 40.0 & 40.0 & 40.0 & 40.0 & 40.0 & 40.0 \\
$\mathrm{PSM}^{1}$ & - & 1.4 & 2.9 & 4.3 & 5.7 & 7.2 \\
$\mathrm{SGA}^{2}$, $\mathrm{mg} \cdot \mathrm{kg}^{-1} \mathrm{diet}$ & - & 60 & 120 & 180 & 240 & 300 \\
Crude protein, $\mathrm{g} \cdot \mathrm{kg}^{-1}$ & 220.0 & 220.0 & 220.0 & 220.0 & 220.0 & 220.0 \\
\hline
\end{tabular}

${ }^{1}$ potato sprout meal, $41.85 \mathrm{mg} \mathrm{SGA} \mathrm{per} \mathrm{g} ;{ }^{2}$ solanidine glycoalkaloids, calculated

animals (Morawski Feed Factory, Poland) was supplemented with increasing amounts of potato sprout meal (PSM) containing $41.85 \mathrm{mg}$ SGA per g of dry matter. The PSM was prepared from sprouts harvested from potatoes prior to planting at the Experimental Station of the State Institute of Plant Breeding and Acclimation in Jadwisin (Poland). Fresh sprouts were dried at $60^{\circ} \mathrm{C}$ for about $24 \mathrm{~h}$, ground in a laboratory mill, analysed for SGA contents (Bergers, 1980) and stored until use. Six diets containing Labofeed $\mathrm{H}$ diet without PSM (control diet No. 1) or supplemented with $1.4,2.9,4.3,5.7$ or $7.2 \mathrm{~g}$ of PSM per $\mathrm{kg}$, were prepared. Due to the scarce literature data, the SGA levels in the experimental diets were chosen according to our best knowledge. The composition and SGA contents of the diets are given in Table 2. The dietary content of SGA and TI activity were calculated from values obtained by analysing potato products.

\section{Animals and experimental procedures}

The experimental procedures were approved by Local Ethics Committee for Animal Experimentation. Both experiments were performed on male Crl:W (Han) Wistar rats, six animals per group, and mean initial body weight 65 and $70 \mathrm{~g}$ in Experiments1 and 2, respectively. The rats were housed 
individually in wire-bottom cages designed to separate faeces and urine, in a room with a $12 \mathrm{~h}$ light- $12 \mathrm{~h}$ dark cycle at $22^{\circ} \pm 1^{\circ} \mathrm{C}$. Experiment 1 comprised 18 days of ad libitum feeding and 6 days of semi ad libitum during total collection of faeces and urine. Experiment 2 comprised 28 days of ad libitum feeding. Feed intake was measured weekly in both experiments. At the end of the experiments, the rats were sacrificed and the stomach, small intestine, caecum (full and empty), liver, pancreas, spleen and kidneys were excised and weighed. Blood was collected into heparinized tubes by intracardiac puncture. Caecal digesta was collected for short-chain fatty acid (SCFA) determination.

\section{Analytical methods and measurements}

Total glycoalkaloids in potato concentrates and sprout meal were analysed as described by Bergers (1980). Trypsin inhibitor activity in PPC was determined using the method of Kakade et al. (1974) and expressed as milligrams of trypsin inactivated by $1 \mathrm{~g}$ of the concentrate.

The nitrogen content of diets, faeces and urine was determined by the standard Kjeldahl method, and dry matter and ash contents of diets and faeces according to AOAC (2000). Selected biochemical parameters of blood plasma were determined on an Ectachem DT60 Analyzer (Eastman Kodak, Rochester, NY, USA). Measurement of the $\mathrm{pH}$ of caecal digesta, preparation of the samples, and analysis of short-chain fatty acids were performed as described by Barszcz et al. (2011).

\section{Statistical analysis}

The effects of diets in Experiments 1 and 2 were subjected to the one-way ANOVA procedure. The design of Experiment 1 was imposed by the composition of the available material that did not allow for separation of the effects of glycoalkaloids and trypsin inhibitor.

The analyses were performed according to the model:

where:

$$
y_{i j}=\mu+\alpha_{i}+e_{i j}
$$

$y_{i j}-i j$-th observation,

$\mu$ - overall mean,

$\alpha_{i}$ - fixed effect of treatment $(i=1,2,3,4,5,6,7$

in Experiment 1 and $i=1,2,3,4,5,6$ in

Experiment 2),

$e_{i j}$-random error connected with $i j$-th observation.

Differences among the groups were evaluated by Fisher-Snedecor test and Tukey HSD test using the STATGRAPHICS ${ }^{\circledR}$ Centurion XVI ver. 16.1.03 (StatPoint Technologies, Inc. 1982-2010) statistical package.

\section{Results}

\section{Experiment 1}

The content of SGA in six diets increased from 116 to $439 \mathrm{mg} \cdot \mathrm{kg}^{-1}$ and the activity of TI contributed by PPC ranged from $0.13-0.14$ to $0.27-0.29$ and $0.42-0.45 \mathrm{mg} \cdot \mathrm{g}^{-1}$ (Table 1 ).

Feed intake was not affected by either diet or SGA and TI. Body weight gain was significantly greater on diet $3\left(125 \mathrm{mg} \cdot \mathrm{kg}^{-1}\right.$ and $0.13 \mathrm{mg} \cdot \mathrm{g}^{-1}$ of SGA and TI, respectively) than on diet $6(331 \mathrm{mg}$. $\mathrm{kg}^{-1}$ and $0.29 \mathrm{mg} \cdot \mathrm{g}^{-1}$ of these compounds), and did not differ among other groups, including the control group (Table 3).

Table 3. Feed intake and body weight gain of rats in Experiments 1 and 2

\begin{tabular}{|c|c|c|c|c|}
\hline \multirow{2}{*}{$\begin{array}{l}\text { Diet } \\
\text { No }\end{array}$} & \multicolumn{2}{|l|}{ Content of } & \multicolumn{2}{|c|}{ Growth performance } \\
\hline & $\begin{array}{l}\mathrm{SGA}{ }^{1} \\
\mathrm{mg} \cdot \mathrm{kg}^{-1}\end{array}$ & $\begin{array}{l}\mathrm{Tl}^{1} \\
\mathrm{mg} \cdot \mathrm{g}^{-1}\end{array}$ & $\begin{array}{l}\text { feed } \\
\text { intake, } g\end{array}$ & $\begin{array}{l}\text { body weight } \\
\text { gain, g }\end{array}$ \\
\hline \multicolumn{5}{|c|}{ Experiment $1^{2}$} \\
\hline 1 & - & - & 254 & $70.5^{\mathrm{ab} 4}$ \\
\hline 2 & 116 & 0.42 & 258 & $75.0^{\mathrm{ab}}$ \\
\hline 3 & 125 & 0.13 & 276 & $87.0^{\mathrm{b}}$ \\
\hline 4 & 164 & 0.45 & 268 & $78.2^{\mathrm{ab}}$ \\
\hline 5 & 215 & 0.14 & 276 & $81.9^{\mathrm{ab}}$ \\
\hline 6 & 331 & 0.29 & 250 & $67.2^{\mathrm{a}}$ \\
\hline 7 & 439 & 0.27 & 259 & $70.2^{\mathrm{ab}}$ \\
\hline SEM & & & 11.0 & 4.28 \\
\hline \multicolumn{5}{|c|}{ Experiment $2^{3}$} \\
\hline 1 & - & - & 542 & 161.6 \\
\hline 2 & 60 & - & 527 & 159.8 \\
\hline 3 & 120 & - & 555 & 168.8 \\
\hline 4 & 180 & - & 553 & 168.9 \\
\hline 5 & 240 & - & 539 & 159.0 \\
\hline 6 & 300 & - & 547 & 161.2 \\
\hline SEM & & & 15.4 & 5.98 \\
\hline
\end{tabular}

${ }^{1}$ see Table $1 ;{ }^{2} 18$ days of feeding trial; ${ }^{3} 28$ days of feeding trial;

${ }^{4}$ values with different letters within the column differ at $p \leq 0.05$

Table 4. Apparent total tract digestibility of protein and organic matter, $\%$; Experiment 1

\begin{tabular}{|c|c|c|c|c|}
\hline \multirow[b]{2}{*}{$\begin{array}{l}\text { Diet } \\
\text { No }\end{array}$} & \multicolumn{2}{|l|}{ Content of } & \multicolumn{2}{|c|}{ Apparent digestibility, \% } \\
\hline & $\begin{array}{l}\mathrm{SGA}^{1} \\
\mathrm{mg} \cdot \mathrm{kg}^{-1}\end{array}$ & $\begin{array}{l}\mathrm{Tl}^{1} \\
\mathrm{mg} \cdot \mathrm{g}^{-1}\end{array}$ & $\begin{array}{l}\text { crude } \\
\text { protein }\end{array}$ & $\begin{array}{l}\text { organic } \\
\text { matter }\end{array}$ \\
\hline 1 & - & - & $90.8^{\mathrm{bc} 2}$ & $94.6^{c}$ \\
\hline 2 & 116 & 0.42 & $90.3^{b}$ & $94.2^{\mathrm{bc}}$ \\
\hline 3 & 125 & 0.13 & $92.2^{\mathrm{c}}$ & $94.3^{\mathrm{bc}}$ \\
\hline 4 & 164 & 0.45 & $90.5^{b}$ & $94.2^{\mathrm{bc}}$ \\
\hline 5 & 215 & 0.14 & $91.2^{\mathrm{bc}}$ & $94.4^{\mathrm{bc}}$ \\
\hline 6 & 331 & 0.29 & $88.4^{a}$ & $93.6^{a}$ \\
\hline 7 & 439 & 0.27 & $88.4^{a}$ & $93.8^{\mathrm{ab}}$ \\
\hline SEM & & & 0.34 & 0.14 \\
\hline
\end{tabular}

${ }^{1}$ see Table 1;

${ }^{2}$ values with different letters within the columns differ at $p \leq 0.05$ 
Table 5. Relative weight of body organs, $\mathrm{g} \cdot 100 \mathrm{~g}^{-1}$ body weight

\begin{tabular}{|c|c|c|c|c|c|c|c|c|c|c|}
\hline \multirow{3}{*}{$\begin{array}{l}\text { Diet } \\
\text { No }\end{array}$} & \multicolumn{2}{|c|}{ Content of } & \multicolumn{8}{|c|}{ Body organs } \\
\hline & \multirow{2}{*}{$\begin{array}{l}\mathrm{SGA}^{1} \\
\mathrm{mg} \cdot \mathrm{kg}^{-1}\end{array}$} & \multirow{2}{*}{$\begin{array}{l}\mathrm{Tl}^{1} \\
\mathrm{mg} \cdot \mathrm{g}^{-1}\end{array}$} & \multirow{2}{*}{ stomach } & \multirow{2}{*}{$\begin{array}{l}\text { small } \\
\text { intestine }\end{array}$} & \multirow{2}{*}{ liver } & \multirow{2}{*}{ pancreas } & \multirow{2}{*}{ spleen } & \multirow{2}{*}{ kidney } & \multicolumn{2}{|c|}{ caecum } \\
\hline & & & & & & & & & full & empty \\
\hline \multicolumn{11}{|c|}{ Experiment 1} \\
\hline 1 & - & - & $0.61^{\mathrm{bc} 2}$ & $2.70^{a}$ & 3.98 & 0.38 & 0.22 & 0.91 & 1.33 & 0.25 \\
\hline 2 & 116 & 0.49 & $0.56^{a}$ & $3.01^{\mathrm{ab}}$ & 3.93 & 0.38 & 0.21 & 0.90 & 1.30 & 0.24 \\
\hline 3 & 125 & 0.13 & $0.57^{\mathrm{ab}}$ & $2.88^{\mathrm{ab}}$ & 4.06 & 0.40 & 0.23 & 0.91 & 1.28 & 0.26 \\
\hline 4 & 164 & 0.45 & $0.58^{\mathrm{ab}}$ & $2.85^{\mathrm{ab}}$ & 4.08 & 0.35 & 0.20 & 0.89 & 1.17 & 0.23 \\
\hline 5 & 215 & 0.14 & $0.56^{a}$ & $2.93^{\mathrm{ab}}$ & 4.16 & 0.39 & 0.22 & 0.86 & 1.33 & 0.26 \\
\hline 6 & 331 & 0.29 & $0.60^{\mathrm{abc}}$ & $3.18^{b}$ & 4.16 & 0.39 & 0.21 & 0.94 & 1.32 & 0.25 \\
\hline 7 & 439 & 0.27 & $0.62^{c}$ & $3.16^{b}$ & 4.14 & 0.37 & 0.21 & 0.94 & 1.25 & 0.25 \\
\hline SEM & & & 0.010 & 0.079 & 0.094 & 0.018 & 0.01 & 0.023 & 0.091 & 0.009 \\
\hline \multicolumn{11}{|c|}{ Experiment 2} \\
\hline 1 & - & - & 0.52 & 2.99 & 4.90 & 0.38 & 0.24 & 0.98 & 2.87 & 0.47 \\
\hline 2 & 60 & - & 0.49 & 3.00 & 4.98 & 0.39 & 0.25 & 0.97 & 3.13 & 0.50 \\
\hline 3 & 120 & - & 0.50 & 2.99 & 4.98 & 0.35 & 0.23 & 0.95 & 2.81 & 0.48 \\
\hline 4 & 180 & - & 0.48 & 2.97 & 5.00 & 0.39 & 0.26 & 0.95 & 3.13 & 0.50 \\
\hline 5 & 240 & - & 0.51 & 3.02 & 4.97 & 0.3 & 0.23 & 0.94 & 3.15 & 0.49 \\
\hline 6 & 300 & - & 0.52 & 2.93 & 4.91 & 0.39 & 0.25 & 0.97 & 3.04 & 0.50 \\
\hline SEM & & & 0.001 & 0.069 & 0.135 & 0.014 & 0.011 & 0.027 & 0.125 & 0.016 \\
\hline
\end{tabular}

${ }^{1}$ see Table $1 ;{ }^{2}$ values with different letters, within the columns differ at $p \leq 0.05$

Apparent total tract digestibility of potato protein contributing up to $215 \mathrm{mg} \mathrm{SGA} \cdot \mathrm{kg}^{-1}$ did not differ from that of casein, whereas digestibility of PPC protein in diets 6 and 7 containing 331 and $439 \mathrm{mg} \cdot \mathrm{kg}^{-1}$ of SGA and TI activity 0.29 and $0.27 \mathrm{mg} \cdot \mathrm{g}^{-1}$, respectively, was significantly lower than in casein- and other PPC-containing diets. Digestibility of organic matter (OM) of casein and PPC diets containing less than $331 \mathrm{mg} \mathrm{SGA} \cdot \mathrm{kg}^{-1}$ did not differ, but OM digestibility of diets 6 and 7 with the highest SGA concentration and moderate TI activity was significantly lower than on the control diet (Table 4).

Only the relative weight of the stomach and small intestine were significantly affected by the diet (Table 5). The weight of the stomach was the greatest in control animals and those fed on diets 6 and 7 with the highest SGA content and moderate TI activity, whereas the weight of the small intestine was the smallest in control animals and the greatest on diets 6 and 7.

The activity of liver enzymes, asparagine aminotransferase and gamma-glutamyltransferase, did not differ among groups. In contrast, the activity of alanine aminotransferase (ALT) was considerably smaller in the control group than on diet 7 (Table 6).

The total concentration of short-chain fatty acids (SCFA) and the concentration of particular acids, except propionic acid, was numerically greater on diets containing PPC than casein (Table 7). The acetic acid concentration was significantly greater on diets 3 and $5\left(125 \mathrm{mg} \cdot \mathrm{kg}^{-1}\right.$ and $215 \mathrm{mg} \cdot \mathrm{kg}^{-1}$ SGA, both low TI: 0.13 and $0.14 \mathrm{mg} \cdot \mathrm{g}^{-1}$ ), that of isobutyric acid was significantly greater on diets 3 and $6\left(125 \mathrm{mg} \cdot \mathrm{kg}^{-1} \mathrm{SGA}, 0.13 \mathrm{mg} \cdot \mathrm{g}^{-1} \mathrm{TI}\right.$, and 331 $\left.\mathrm{mg} \cdot \mathrm{kg}^{-1} \mathrm{SGA}, 0.29 \mathrm{mg} \cdot \mathrm{g}^{-1} \mathrm{TI}\right)$. The concentrations of butyric and isovaleric acids varied in an irregular manner, whereas the concentrations of valeric acid in all groups, except on diet $4\left(164 \mathrm{mg} \cdot \mathrm{kg}^{-1} \mathrm{SGA}\right.$, $0.45 \mathrm{mg} \cdot \mathrm{g}^{-1} \mathrm{TI}$ ), were significantly greater than on casein and did not differ among PPC. The SCFA

Table 6. Activity of liver enzymes in rats, Experiments 1 and 2

\begin{tabular}{|c|c|c|c|c|c|}
\hline \multirow[b]{2}{*}{$\begin{array}{l}\text { Diet } \\
\text { No }\end{array}$} & \multicolumn{2}{|l|}{ Content of } & \multicolumn{3}{|c|}{ 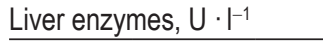 } \\
\hline & $\begin{array}{l}\mathrm{SGA}^{1} \\
\mathrm{mg} \cdot \mathrm{kg}^{-1}\end{array}$ & $\begin{array}{l}\mathrm{Tl}^{1} \\
\mathrm{mg} \cdot \mathrm{g}^{-1}\end{array}$ & $\mathrm{AST}^{2}$ & $\mathrm{GGT}^{3}$ & $\mathrm{ALT}^{4}$ \\
\hline \multicolumn{6}{|c|}{ Experiment 1} \\
\hline 1 & - & - & 53.9 & 5.7 & $12.7^{\mathrm{a} 5}$ \\
\hline 2 & 116 & 0.42 & 51.5 & 5.6 & $19.6^{\mathrm{ab}}$ \\
\hline 3 & 125 & 0.13 & 49.1 & 5.8 & $15.4^{\mathrm{ab}}$ \\
\hline 4 & 164 & 0.45 & 55.5 & 5.9 & $18.7^{\mathrm{ab}}$ \\
\hline 5 & 215 & 0.14 & 52.6 & 5.4 & $15.2^{\mathrm{ab}}$ \\
\hline 6 & 331 & 0.29 & 55.9 & 5.7 & $20.0^{\mathrm{ab}}$ \\
\hline 7 & 439 & 0.27 & 60.0 & 6.0 & $20.9^{b}$ \\
\hline SEM & & & 3.12 & 0.23 & 1.85 \\
\hline \multicolumn{6}{|c|}{ Experiment 1} \\
\hline 1 & - & - & 74.4 & - & 49.0 \\
\hline 2 & 60 & - & 83.4 & - & 51.5 \\
\hline 3 & 120 & - & 72.1 & - & 43.4 \\
\hline 4 & 180 & - & 71.3 & - & 54.7 \\
\hline 5 & 240 & - & 77.1 & - & 55.5 \\
\hline 6 & 300 & - & 73.9 & - & 47.1 \\
\hline SEM & & & 1.81 & - & 1.72 \\
\hline
\end{tabular}

${ }^{1}$ see Table $1 ;{ }^{2}$ aspartate aminotransferase; ${ }^{3}$ gamma-glutamyltransferase; ${ }^{4}$ alanine aminotransferase; ${ }^{5}$ values with different letters within the columns differ at $p \leq 0.05$ 
Table 7. Short-chain fatty acids (SCFA) concentration in caecum, $\mu \mathrm{mol} \cdot \mathrm{g}^{-1}$ digesta; Experiments 1 and 2

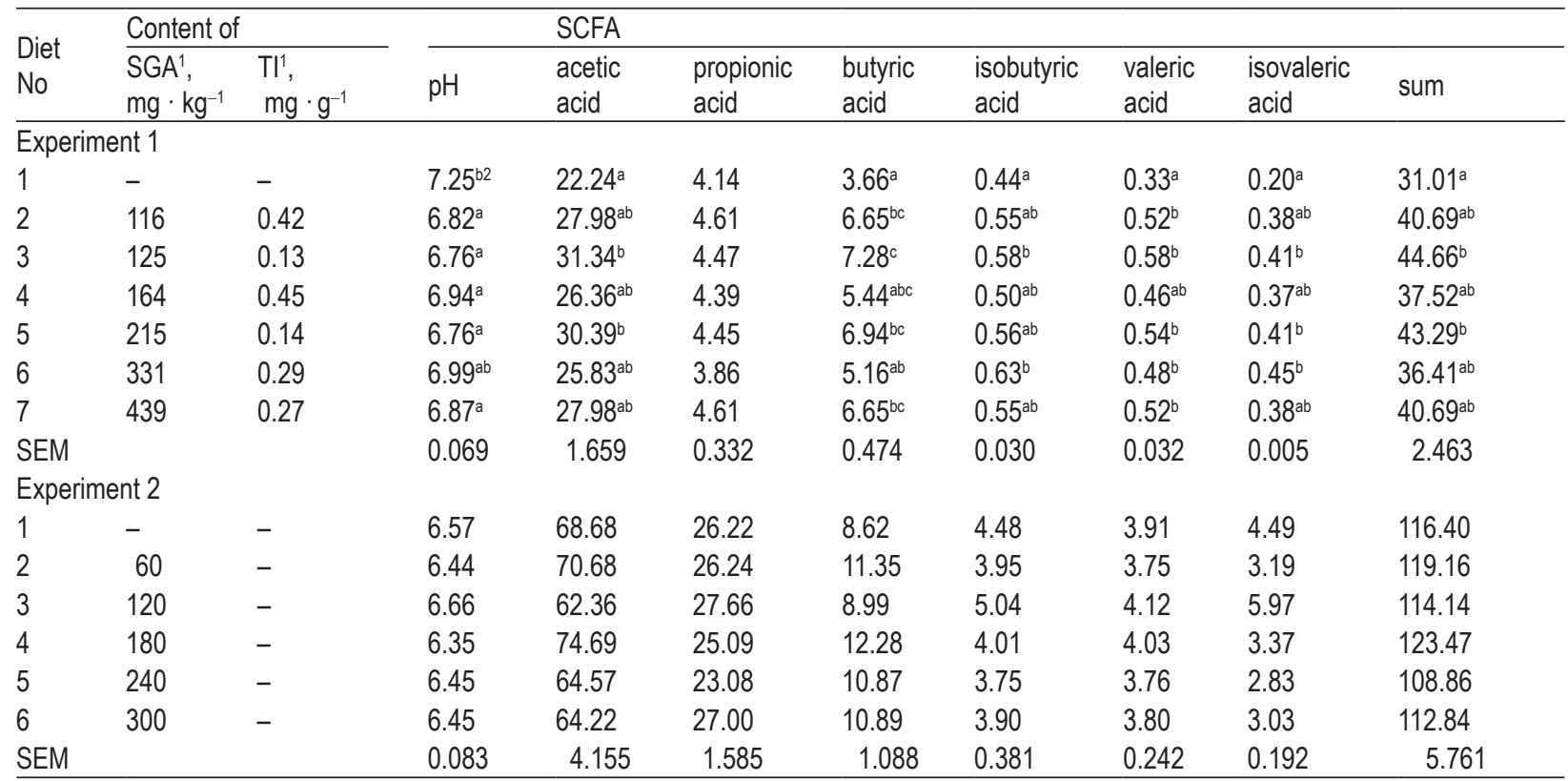

${ }^{1}$ see Table $1 ;{ }^{2}$ values with different letters within the columns differ at $p \leq 0.05$

profile differed slightly between the casein and PPC diets, the proportions of propionic acid being smaller and those of butyric, isovaleric and valeric acids, greater on PPC than on the casein diet, whereas the proportions of acetic and isobutyric acids were similar (not shown). The $\mathrm{pH}$ of caecal digesta of rats fed PPC diets was substantially lower than on casein (Table 7)

\section{Experiment 2}

No effect on growth performance, weight of body organs, biochemical blood parameters, or intensity of fermentation was found of the diets containing commercial feed supplemented with potato sprout meal to contain from 0 to $300 \mathrm{mg} \mathrm{SGA} \cdot \mathrm{kg}^{-1}$ (Tables 3, 5, 6 and 7).

\section{Discussion}

Potato concentrate fed to rats as the only source of protein in semi-purified diets did not reduce feed intake, as compared with casein, and numerically even increased body weight gain, except in diets 6 and 7. This may be attributed to the excellent potato protein amino acid composition, as has been reported by many authors (Xie and Jokumsen, 1997; Jin et al., 2008; Ohh et al., 2009; Lynch et al., 2012). Moreover, contrary to expectations, growth performance parameters were not negatively affected by the increase of dietary SGA content up to $330 \mathrm{mg}$. $\mathrm{kg}^{-1}$ in Experiment 2 and to $439 \mathrm{mg} \cdot \mathrm{kg}^{-1}$ in Experiment 1 . The only statistically significant difference between the greater body weight of rats fed on diets containing low levels of SGA and TI and those fed on a high level of SGA and moderate level of TI (diet 3 vs 6) could not be attributed to the effect of SGA. These results contrast with the common opinion on glycoalkaloids as the main factor responsible for depression of feed intake and growth rate of piglets and fish fed PPC (Kerr et al., 1998). Also chickens were less tolerant to SGA than rats, since in an experiment of similar design, birds fed a diet containing $318 \mathrm{mg} \mathrm{SGA} \cdot \mathrm{kg}^{-1}$ substantially decreased both feed intake and growth rate (Tuśnio et al., 2013). The discrepancy between the reported results and those of our study may probably be explained by the smaller sensibility of rats than other animal species to alkaloids, but may also result from the different type and composition of the diets affecting animal response to SGA.

Since the design of Experiment 1 did not allow for application of two-factorial analysis of variance separating the effects of SGA and TI and showing their interaction, it may be only speculated that the smallest body weight gain on diets 6 and 7 containing 331 and $439 \mathrm{mg} \cdot \mathrm{kg}^{-1}$ of SGA and TI activity of 0.29 and $0.27 \mathrm{mg} \cdot \mathrm{g}^{-1}$, respectively, could be the effect of the interaction of both compounds.

The effects of the potato protease inhibitor found in Experiment 1 show that also TI should be considered as the antinutritional factor in potato concentrate, since even relatively low dietary concentrations may depress growth rate and gut functions. The increase of TI activity from 0.13 to 0.42 and from 0.14 to $0.45 \mathrm{mg} \cdot \mathrm{g}^{-1}$ of the diet induced a small depression of apparent protein digestibility, but did not affect the digestibility of organic matter. 
The effect of TI on protein digestibility, but not on growth performance, is in line with the results of Tuśnio et al. (2013) on chicken and those of Bajko et al. $(1979,1980)$ and Lee et al. $(1985)$ who found that potato trypsin inhibitor stimulates exocrine pancreatic secretion and affects protein digestibility in a similar way as the protease inhibitors present in soya bean. However, in contrast to the common observation on the hypertrophy of rat pancreas induced by soya bean inhibitors, such an effect of the TI of potato origin was not observed in our experiment.

The structures and activities of many potato protease inhibitors have been recently studied with particular emphasis on their role as antimicrobial and antifungal factors (Kim et al., 2005; Park et al., 2005; Jin et al., 2008). It has been postulated that potato protein of particular potato varieties may be an alternative to medicated feeds due to its antimicrobial activity (Jin et al., 2008). The results of our study show that the trypsin inhibitor present in potato protein concentrate produced from potatoes of different varieties does not reduce the intensity of bacterial fermentation in the large intestine of rats, whereas its effect on pathogenic strains was not estimated.

In view of the presented results it is concluded that potato trypsin inhibitor should be considered as an important antinutritional factor and its tolerated levels should be estimated both independently and in a well-defined interaction with glycoalkaloids, since both compounds are present in PPC in widely varying amounts (Pastuszewska et al., 2009).

The elevated level of liver enzyme ALT at the highest SGA concentrations in Experiment 1 imply hepatotoxicity of these compounds when fed at the concentration of $439 \mathrm{mg} \cdot \mathrm{kg}^{-1}$ and are in line with the tendency towards increased relative liver weight. The enhanced activity of these enzymes is indicative of impairment of liver functions by toxins, including glycoalkaloids (Rupin et al., 1982; Friedman, 1996). The response of rats differs in this aspect from that of chickens, in which a slight but non-significant decrease of AST activity was found at a similar SGA concentration (Tuśnio et al., 2013).

Bacterial fermentation was far more intensive in animals fed on natural ingredient diets in Experiment 2 than on semi-purified diets in Experiment 1, and was also slightly more intensive on semi-purified diets containing potato protein than casein. The conclusion on the stimulating effect of potato protein on caecal fermentation is based on the significantly lower $\mathrm{pH}$ of caecal digesta and numerically greater sum of SCFA on PPC diets. This result corroborates the hypothesis of Morita et al. (2004) on the role of potato protein as a resistant protein providing gut microflora with a greater amount of nitrogen than does casein, which is almost completely digested in the small intestine. Among the particular SCFA, the most regular and important modifications were found for the concentration and proportions of butyric and valeric acids, which were substantially increased in rats fed on potato protein. The rise in the butyric acid concentration is in agreement with the results of an earlier study by Taciak and Pastuszewska (2007).

Glycoalkaloids appeared to influence fermentation in rats fed semi-purified diets in Experiment 1, but not the natural ingredient diets in Experiment 2. The modifications consisted in the changes in the concentrations of isobutyric and isovaleric acids, the products of bacterial metabolism of branchedchain amino acids. This may suggest that SGA affect the composition of protein catabolized by microflora in the large intestine, probably due to the stimulation of endogenous secretion. This interpretation is supported by the negative effect of SGA on apparent protein digestibility in the whole digestive tract. Since one of two mechanisms of the harmful effects of SGA in organisms is disintegration of cell membranes, including those of the intestinal epithelium (Smith et al., 1996), it may be hypothesized that impairment of digestion was caused by damage of this structure.

The results of the present study show that the dietary concentration of glycoalkaloids tolerated by rats depends on the type of the diet and varies depending on the criterion applied. Animals fed a semi-purified low-protein diet only slightly stimulating fermentation were more affected by SGA than animals fed a commercial breeding diet resulting in substantially more intensive fermentation. The microbial fermentation rate may be important, since in vitro studies have shown that rumen microorganisms hydrolyse SGA to less toxic compounds (Kuiper-Goodman and Nawrot, 1996), therefore, similar effects of the microflora of the large intestine of monogastric animals may be assumed.

When growth performance of rats fed the semipurified diet was the main parameter, the tolerated level was about $331 \mathrm{mg} \cdot \mathrm{kg}^{-1}$, but could not be clearly discriminated because of likely interactive effects of TI. Small but distinct depression of protein and organic matter digestibility indicating impairment of gut functions may imply that the tolerated level is below $330 \mathrm{mg} \cdot \mathrm{kg}^{-1}$ of SGA, whereas appearance of metabolic effects not earlier than at the highest 
SGA concentration suggests that it is between 330 and $440 \mathrm{mg} \cdot \mathrm{kg}^{-1}$. It should be stressed that the increase of SGA content within the experimental range did not provoke any evident symptoms of toxicity or neural disorders.

\section{Conclusions}

The dietary concentration of glycoalkaloids tolerated by rats depends on type of the diet and varies depending on the criterion applied. Substitution of potato protein for casein in a semi-purified diet increases the intensity of microbial fermentation and modifies the short-chain fatty acid profile in rats. The less apparent effects of solanidine glycoalkaloids in animals fed natural ingredients than the semi-purified diet may probably be explained by a greater intensity of microbial fermentation. Potato trypsin inhibitor should be considered as an important antinutritional factor in potato protein concentrate, but its effects on the pancreas seem to differ from those of soya bean TI.

\section{Acknowledgements}

The authors thank Miss J. Jankowiak and Mr Ł. Staśkiewicz for technical assistance.

\section{References}

AOAC, 2000. Association of Official Analytical Chemists, Official Methods of Analysis. $17^{\text {th }}$ Edition. Arlington, VA

Bajko K., Szałaj W., Gabryelewicz A., Musiałowicz B., Worowski K., 1979. Effect of potato inhibitor of proteolytic enzymes on activity and morphology of the rat pancreas. Acta Physiol. Pol. 30, 365-371

Barszcz M., Taciak M., Skomiał J., 2011. A dose-response effects of tannic acid and protein on growth performance, caecal fermentation, colon morphology, and B-glucuronidase activity of rats. J. Anim. Feed Sci. 20, 613-625

Bergers W.W.A., 1980. A rapid quantitative assay for solanidine glycoalkaloids in potatoes and industrial potato protein. Potato Res. 23, 105-110

Fernando P.S., Rose S.P., Mackenzie A.M., Silva S.S.P., 2011. Effects of diets containing potato protein or soya bean meal on the incidence of spontaneously-occuring subclinical necrotic enteritis and the physiological response in broiler chickens. Brit. Poultry Sci. 52, 106-114

Friedman M., Henika P.R., Mackey B.E., 1996. Feeding potato, tomato and eggplant alkaloids affects food consumption and body and liver weights in mice. J. Nutr. 126, 989-999

Jin Z., Yang Y.X., Choi J.Y., Shinde P.L., Yoon S.Y., Hahn T.-W., Lim H.T., Park Y., Hahm K.-S., Joo J.W., Chae B.J., 2008. Potato (Solanum tuberosum L. cv. Gogu valley) protein as a novel antimicrobial agent in weanling pigs J. Anim. Sci. 86, 1562-1572
Kakade M.L., Rackis J.J., McGhee J.E., Puski G., 1974. Determination of trypsin inhibitor activity of soy products: A collaborative analysis of an improved procedure. Cereal Chem. 51, 376-382

Kerr C.A., Goodband R.D., Smith J.W., Musser R.E., Bergstrom J.R., Nessmith W.B., Tokach M.D., Nelssen J.L., 1998. Evaluation of potato protein on the growth performance of early weaned pigs. J. Anim. Sci. 76, 3024-3033

Kim J.-Y., Park S.-C., Kim M.-H., Lim H.-T., Park Y., Hahm K.-S., 2005. Antimicrobial activity studies on a trypsin - chymotrypsin protease inhibitor obtained from potato. Biochem. Biophys. Res. Commun. 330, 921-927

Kuiper-Goodman T., Nawrot P.S., 1996. Solanine and Chaconine. In: Toxicological Reports on Alkaloids. http:// www.nopotato.com

Lee S.S., Liener I.E., Desborough S., 1985. Comparative effects of feeding a protease inhibitor enriched potato protein concentrate and soy flour to rats. Plant Food Hum. Nutr. 35, 9-19

Lynch B., Simon R.R., van Otterdijk F.M., Emmen H.H., Giuseppin M.L.F., Kemme-Kroonsberg C., 2012. Subchronic toxicity evaluation of potato protein isolates. Food Chem. Toxicol. 50, 373-384

Morita T., Kasaoka S., Kiriyama S., 2004. Physiological functions of resistant proteins: proteins and peptides regulating large bowel fermentation of indigestible polysaccharides. J. AOAC Int. 87, 792-796

Ohh S.H., Shinde P.L., Jin Z., Choi J.Y., Hahn T.-W., Lim H.T., Kim G.Y., Park Y., Hahm K.-S., Chae B. J., 2009. Potato (Solanum tuberosum L. Cv. Gogu valley) protein as an antimicrobial agent in the diets of boilers. Poultry Sci. 88, 1227-1234

Palliyeguru M.W.C.D., Rose S.P., Mackenzie A.M., 2010. Effect of dietary protein concentrates on the incidence of subclinical necrotic enteritis and growth performance of broiler chickens. Poultry Sci. 89, 34-43

Park Y., Choi B.H., Kwak J.-S., Kang C.-W., Lim H.-T., Cheong H.S., Hahm K.-S., 2005. Kunitz-type serine protease inhibitor from potato (Solanum tuberosum L. CV. Jopung). J. Agr. Food Chem. 53, 6491-6496

Pastuszewska B., Taciak M., Tuśnio A., Mazurczyk W., 2009. Variability in the composition of potato protein concentrates produced in different starch factories. A preliminary survey. Anim. Feed Sci. Tech. 154, 260-264

Taciak M., Pastuszewska B., 2007. Potato protein concentrate - nutritional value and effects on gut morphology, ileal digestibility, and caecal fermentation in rats. In: I. Ortigues-Marty, N. Miraux, W. Brand-Williams (Editors). Energy and Protein Metabolism and Nutrition. EAAP Publications No. 124, Vichy (France), pp. 627-628

Tuśnio A., Pastuszewska B., Święch E., Taciak M., 2011. Response of young pigs to feeding potato protein and potato fibre - nutritional, physiological and biochemical parameters. J. Anim. Feed Sci. 20, 361-378

Tuśnio A., Pastuszewska B., Taciak M., Mieczkowska A., Smulikowska S., 2013. Response of growing chicken to potato protein concentrates providing different amounts of solanidine glycoalkaloids and trypsin inhibitor. Arch. Geflügelk. 77, 51-58

Xie S., Jokumsen A., 1997. Replacement of fish meal by potato protein concentrate in diets for rainbow trout, Oncorhynchus mykiss (Walbaum): growth, feed utilization and body composition. Aquacult. Nutr. 3, 65-69 